\title{
An iridovirus-like agent isolated from the ornate burrowing frog Limnodynastes ornatus in northern Australia
}

\author{
R. Speare*, J. R. Smith \\ Graduate School of Tropical Veterinary Science and Agriculture, James Cook University of North Queensland, \\ Townsville 4811, Australia
}

\begin{abstract}
An enveloped, icosahedral DNA virus of $128 \pm 8 \mathrm{~nm}$ was isolated from metamorphs of the ornate burrowing frog Limnodynastes ornatus (Gray) in Australia. At $25^{\circ} \mathrm{C}$ the virus grew readily in 11 mammalian and 4 fish cell lines $\left(\mathrm{TCID}_{50} \mathrm{ml}^{-1}=1 \times 10^{5.43}\right.$ to $\left.10^{8.85}\right)$, grew less well in the Atlantic salmon cell line $\left(\mathrm{TCID}_{50} \mathrm{ml}^{-1}=1 \times 10^{3.85}\right)$ and failed to grow in 5 insect cell lines. Growth was inhibited at temperatures above $33^{\circ} \mathrm{C}$. Cytopathic effects consisted of basophilic cytoplasmic inclusion bodies, rounding of infected cells, lifting from substrate and extensive destruction of the monolayer usually by 24 to $48 \mathrm{~h}$ postinfection. Methylation of DNA occurred during growth. The virus shares characteristics with Iridoviridae of amphibian origin, e.g. Ranavirus, and piscine origin, e.g. epizootic haematopoeitic necrosis virus of redfin perch Perca fluviatilis.
\end{abstract}

\section{INTRODUCTION}

Interest in the pathogens of amphibians in Australia has been stimulated by the desire to limit the progressive expansion of the range of the cane toad Bufo marinus L. B. marinus was introduced from South America via Hawaii in 1935 to control beetle pests in sugar cane, but subsequently became a pest species itself (Freeland 1985). Although there are only a few examples of successful biological control of vertebrates (Spratt 1990), a program to investigate the pathogens of B. marinus was commenced (Freeland 1985). At the inception of the program no viruses had been reported from amphibians in Australia and viruses had not been found in B. marinus elsewhere (Speare 1990). Subsequently an irido-like virus was observed in erythrocytes of B. marinus from Costa Rica (Speare et al. 1991).

Viruses with the characteristics of Adenoviridae, Caliciviridae, Herpesviridae, Iridoviridae, Papovaviridae and Togaviridae have been found in amphibians in North and South America and in Europe (Granoff 1983, 1989, Speare et al. 1991).

\footnotetext{
- Present address: Anton Breinl Centre for Tropical Health and Medicine, James Cook University of North Queensland, Townsville 4811, Australia
}

During a study on the pathogens of the cane toad in Australia a cytopathic viral agent was isolated from metamorphs of the ornate burrowing frog Limnodynastes ornatus (Gray). These had been collected as tadpoles from a temporary pond in a backyard at Bohle, a suburb of Thuringowa in north Queensland, Australia $\left(19^{\circ} 16^{\prime} \mathrm{S}, 146^{\circ} 47^{\prime} \mathrm{E}\right)$, and maintained in a glass aquarium for several weeks. Investigation was prompted by deaths of the frogs during or soon after metamorphosis. This paper describes some of the characteristics of a virus isolated from the metamorphs.

\section{MATERIAL AND METHODS}

Isolation of virus. Whole froglets or tissues were macerated, suspended in Dubeco's Miminum Essential

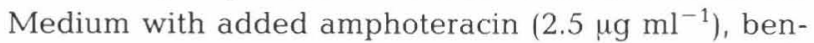
zyl penicillin $\left(200 \mathrm{IU} \mathrm{ml}^{-1}\right)$, gentamycin $\left(200 \mu \mathrm{g} \mathrm{ml} \mathrm{m}^{-1}\right)$ (DMEM), centrifuged at $10000 \mathrm{rpm}$ at $15^{\circ} \mathrm{C}$ and $0.2 \mathrm{ml}$ of the supernatant placed for $2 \mathrm{~h}$ at $25^{\circ} \mathrm{C}$ on monolayers of bluegill fry-2 cells (BF-2) (Wolf et al. 1966) grown in glass test tubes with $12 \times 8 \mathrm{~mm}$ coverslips. After adsorption $2 \mathrm{ml}$ of DMEM with $5 \%$ foetal bovine serum (FBS) was added to each test tube and the cultures were incubated at $25^{\circ} \mathrm{C}$. The following tests were performed using virus of third to fifth passage. 
Cytopathic effect. Cytopathic effect (CPE) was observed in unstained infected cell cultures by the use of an inverted microscope. Infected cells on glass coverslips $(12 \times 8 \mathrm{~mm})$ were fixed in Bouin's solution and staining was done with haematoxylin and eosin using standard techniques. Timed infections to determine when inclusion bodies first appeared were done by inoculation of cell cultures on glass coverslips and staining at $0.5,1,2,3,4,5,6,9,12$ and $24 \mathrm{~h}$ post infection.

Electron microscopy. Infectious BF-2 culture medium was centrifuged at $10000 \mathrm{rpm}$ for $10 \mathrm{~min}$. Virus was examined from both supernatant and lysed pellet using air drying on Formvar-coated copper grids and staining with $2 \%$ phosphotungstic acid (PTA). Thin sections were prepared from BF-2 cells $12 \mathrm{~h}$ after inoculation. Cells were suspended with antibiotic-tryp$\sin (0.05 \%)$-versene solution, pelleted by centrifugation at $10000 \mathrm{rpm}$ for $10 \mathrm{~min}$, fixed with $2.5 \%$ glutaraldehyde, rinsed twice in $0.1 \mathrm{M}$ sodium cacodylate buffer for $10 \mathrm{~min}$, post-fixed in buffered $1 \%$ osmium tetroxide at room temperature for $1 \mathrm{~h}$, rinsed in $0.1 \mathrm{M}$ sodium cacodylate buffer for $10 \mathrm{~min}$, and dehydrated in a graded series of ethanol to $100 \%$. Tissue was infiltrated in 1:1 Spurr's resin:ethanol overnight and embedded in Spurr's resin and polymerised at $75^{\circ} \mathrm{C}$ overnight. Sections of $500 \AA$ thickness were cut on an LKB ultratome, mounted on copper grids, stained in saturated uranyl acetate in $70 \%$ methanol and in lead citrate. Samples were examined at $80 \mathrm{kV}$ on a Joel 2000 FX transmission electron microscope.

Titration of virus. Samples for titre determination were collected, frozen at $-70^{\circ} \mathrm{C}$ for periods of $1 \mathrm{wk}$ to $3 \mathrm{mo}$, thawed by immersion in water at $37^{\circ} \mathrm{C}$ and determinations done in batches for each experiment using BF-2 cells, flat-bottomed plastic microtitre trays and 10 -fold dilutions. Unstained CPE was determined grossly using an inverted microscope. Titres (TCID $_{50}$ $\mathrm{ml}^{-1}$ ) were determined by the technique of Reed \& Muench (1938).

Treatment with ether. One $\mathrm{ml}$ of diethyl ether was added to $2 \mathrm{ml}$ of BF-2 tissue culture fluid with virus, mixed by vortication and samples collected from test culture fluid with lipid solvent and from the control culture fluid after 18 at $4{ }^{\circ} \mathrm{C}$ (Andrewes \& Horstmann 1949). Samples were frozen and processed for titre as indicated above.

Treatment with different $\mathbf{p H}$. The changes in titres with pHs of $2,3,4,5,6,7,8,9,10$ and 11 were studied at $1 \mathrm{~h}$ (Ketler et al. 1962). Hydrochloric acid (1 $\mathrm{M} \mathrm{HCl}$ ) and sodium hydroxide $(10 \mathrm{M} \mathrm{NaOH})$ were added to DMEM to produce the desired acid and alkaline pHs respectively. Virus in $0.5 \mathrm{ml}$ of tissue culture fluid was added to $5 \mathrm{ml}$ of the test solution, a $0.5 \mathrm{ml}$ aliquot removed at the chosen time, added to $4.5 \mathrm{ml}$ of DMEM, and final $\mathrm{pH}$ adjusted to neutrality using either $\mathrm{HCl}$ or $\mathrm{NaOH}$. Samples were frozen and processed for titre as indicated above.

Heat sensitivity. Change in titres at temperatures of 25,37 and $56{ }^{\circ} \mathrm{C}$ were measured over $6 \mathrm{~h}$. Virus in $5 \mathrm{ml}$ of DMEM in glass test tubes $(150 \mathrm{~mm}$ long $\times 15 \mathrm{~mm}$ wide) was held in waterbaths at 37 and $56^{\circ} \mathrm{C}$ and in an incubator at $25^{\circ} \mathrm{C}$ and $0.75 \mathrm{ml}$ samples removed at 0.5 , 1,2 and $6 \mathrm{~h}$, care being taken to avoid viral contamination of the upper portions of the test tubes (Kettler et al. 1962). Samples were frozen and processed for titre as indicated above.

Effect of temperature on growth. Cell cultures of the fish cell lines Atlantic salmon (AS), brown bullhead (BB), BF-2, fat head minnow (FHM) and rainbow trout gonad (RTG), and the mammalian cell lines Madin Darby bovine kidney (MDBK), Vero (American Type Culture Collection 1988), Dunnart (CSL235) (Commonwealth Serum Laboratories 1977), porcine standard/ equine kidney (PS/EK) (Gorman et al. 1975), feline kidney (FK) (Smith 1986) and bovine trachea (BT) were inoculated with $50 \mu \mathrm{l}$ of media containing $10^{8}$ TCID $\mathrm{ml}^{-1}$, absorbed for $1 \mathrm{~h}$ and replaced with fresh DMEM with $5 \%$ FBS. Flasks were incubated at 20, 25, 30, 34 and $37^{\circ} \mathrm{C}$, and CPE was noted and samples collected at $7 \mathrm{~d}$ post-inoculation. Samples were frozen and processed for titre as indicated above.

Nucleic acid. To determine the type of nucleic acid present in viral inclusions, cell cultures were stained with acridine orange (Thompson 1966). At $6 \mathrm{~h}$ after infection, cell cultures of BF-2 were fixed in 50:50 diethyl ether:95\% ethanol for $30 \mathrm{~min}$, hydrated through 80, 70 and $50 \%$ ethanol, rinsed in distilled water, treated with $1 \%$ acetic acid for $6 \mathrm{~s}$, stained in $0.1 \%$ acridine orange for $3 \mathrm{~min}$, washed in McTlvaine's citric acid buffer at pH 3.8 for $1 \mathrm{~min}$, differentiated in $0.1 \mathrm{M}$ calcium chloride for $30 \mathrm{~s}$, mounted in 1 drop of buffer and examined immediately by ultraviolet light (BG 38 filter to give wavelength of about $300 \mathrm{~nm}$ ) with a Zeiss Photomicroscope II with Zeiss III RS incident light fluorescence attachment.

DNA inhibition was tested by the use of pyrimidine analogues and prevention of this inhibition with thymidine (Hamparian et al. 1960). BF-2 cell cultures and media containing the inhibiting pyrimidine analogues 5-bromo-2'-deoxyuridine (BUdR) and 5-iodo-2' -deoxyuridine (IUdR) at concentrations of 100 and $200 \mu \mathrm{g} \mathrm{ml}^{-1}$ were used. Prevention of this inhibition was tested by the addition of thymidine at 100 and $500 \mu \mathrm{g} \mathrm{ml}^{-1}$ with each concentration of DNA inhibitor. A $2 \mathrm{ml}$ inoculum of virus in DMEM $\left(\operatorname{TCID}_{50} \mathrm{ml}^{-1}=1 \times 10^{7}\right)$ was placed on each cell culture and removed after $1 \mathrm{~h}$. After the cell culture was washed 3 times with DMEM, DMEM containing the DNA inhibitor with or without thymidine was added. Samples were collected after addi- 
tion of the new media and at $7 \mathrm{~d}$ post-infection. Titres were determined in the usual manner, but with the addition of thymidine at $250 \mu \mathrm{g} \mathrm{ml}^{-1}$ in titre trays.

Methylation of DNA was evaluated by inhibition with 5-azacytidine (AZC) (Goorha et al. 1984). Virus $\left(\mathrm{TCID}_{50} \mathrm{ml}^{-1}=1 \times 10^{7}\right)$ was absorbed to BF-2 cell cultures for $1 \mathrm{~h}$ and media replaced with DMEM containing $2.5 \mu \mathrm{g} \mathrm{ml}^{-1}$ of AZC. Samples were collected after media change and at $7 \mathrm{~d}$ post-inoculation. Samples were frozen and processed for titre as indicated above.

Statistical analyses. Results for replication in different cell lines at different temperatures were analysed by Statistix 3.1 (Analytic Software, St. Paul, MN, USA) using 1-way analysis of variance (ANOVA) and general analysis of variance with least squares difference (GANOVA). For these analyses results from insect cell lines and AS were omitted since replication did not occur in the former and was minimal in the latter.

\section{RESULTS}

\section{Isolation of virus}

CPE was detected in the initial isolations at $48 \mathrm{~h}$ and was reproduced by inoculation into fresh BF-2 cultures. In subsequent passages monolayers were destroyed within $24 \mathrm{~h}$ at $25^{\circ} \mathrm{C}$. CPE developed in all mammalian and piscine cell lines, but in none of the insect cell lines (Table 1). Titres did not increase after inoculation into 3 mosquito cell lines (see Table 4).

The initial change in unstained cell sheets was rounding of cells with increased refractility. Plaques had centres largely devoid of cells and with affected cells aggregated at the circumference. Aggregated cells subsequently lifted and floated into the media. Total destruction of the monolayers usually took 24 to $48 \mathrm{~h}$ at $25^{\circ} \mathrm{C}$. Initially in cell cultures of BF-2 there were cytoplasmic inclusion bodies and no other cytopathology (Fig. 1b). Inclusion bodies (IB) were basophilic, roughly oval to spherical, occasionally with irregular margins, surrounded by a narrow halo; single or more commonly multiple with up to $7 \mathrm{IB} \mathrm{cell}^{-1}$. Later in the infection (Fig. 1c) the inclusion bodies were more basophilic, more often spherical, and larger, measuring $3.21 \pm 0.86 \mu \mathrm{m}$ (range: 2.4 to $5.7 \mu \mathrm{m}$ ). There were fewer inclusion bodies per cell and it was uncommon to find more than 2. At this stage the cytoplasm of infected cells was finely granular, strongly eosinophilic, particularly close to the nucleus. Many nuclei were pyknotic, irregular in outline and bean-shaped forms were common. In many cells inclusion bodies were enclosed in the concave hollow of the pyknotic nucleus. The nuclear chromatin had lost its fine granularity and was
Table 1. Cell lines inoculated with the virus isolated from Limnodynastes ornatus and appearance of cytopathic effect (CPE) $7 \mathrm{~d}$ after infection at $25^{\circ} \mathrm{C}$. (+): CPE present; (-): CPE absent

\begin{tabular}{|llc|}
\hline Cell line & $\begin{array}{l}\text { Source of } \\
\text { line }\end{array}$ & CPE \\
\hline Insect cell lines & & \\
AA.20A & Mosquito & - \\
AG.55 & Mosquito & - \\
AS.43 & Mosquito & - \\
AM.60 & Mosquito & - \\
C6.36 & Mosquito & - \\
Fish cell lines & & \\
Atlantic salmon (AS) & Fish & + \\
Brown bullhead (BB) & Fish & + \\
Bluegill fry 2 (BF-2) & Fish & + \\
Fathead minnow (FHM) & Fish & + \\
Rainbow trout gonad (RTG) & Fish & + \\
Mammalian cell lines & & \\
Baby hamster kidney (BHK21) & Rodent & + \\
Bovine turbinate (BT) & Cow & + \\
Dunnart (CSL235) & Marsupial & + \\
Feline kidney (FK) & Cat & + \\
G361 & Mouse & + \\
Hela & Human & + \\
Madin Darby bovine kidney (MDBK) & Cow & + \\
Ovine lung (OL) & Sheep & + \\
Porcine standard/equine kidney (PS/EK) & Horse/pig & + \\
Swine testis (ST) & Pig & + \\
Vero & Monkey & + \\
3T3 & Mouse & + \\
& & \\
\hline
\end{tabular}

aggregated below the nuclear membrane or was clumped. Prior to lifting from the coverslip, the affected cells were shrunken with markedly eosinophilic cytoplasm. Nuclei were irregular in outline and pyknotic with increased basophilia. Inclusion bodies were dense and spherical as before, but some affected cells had no inclusion bodies. The affected cells aggregated into foci of pyknotic nuclei, shrunken eosinophilic cytoplasm and spherical inclusion bodies to form a jumble of structures in which it was difficult to make out individual cell outlines. In timed infections with BF-2 cells inclusion bodies were first detected at $3 \mathrm{~h}$. By $6 \mathrm{~h}$ other cytopathology (as described above) was common and by $12 \mathrm{~h}$ the monolayers were totally destroyed.

\section{Morphology of virus}

Viral particles seen by negative contrast were roughly circular with occasional hexagonal outlines and frequently enveloped (Fig. 2). Particles frequently stained with PTA and consisted of a central spherical core surrounded by a membrane abutting against the capsid with an external envelope. The diameter of the 

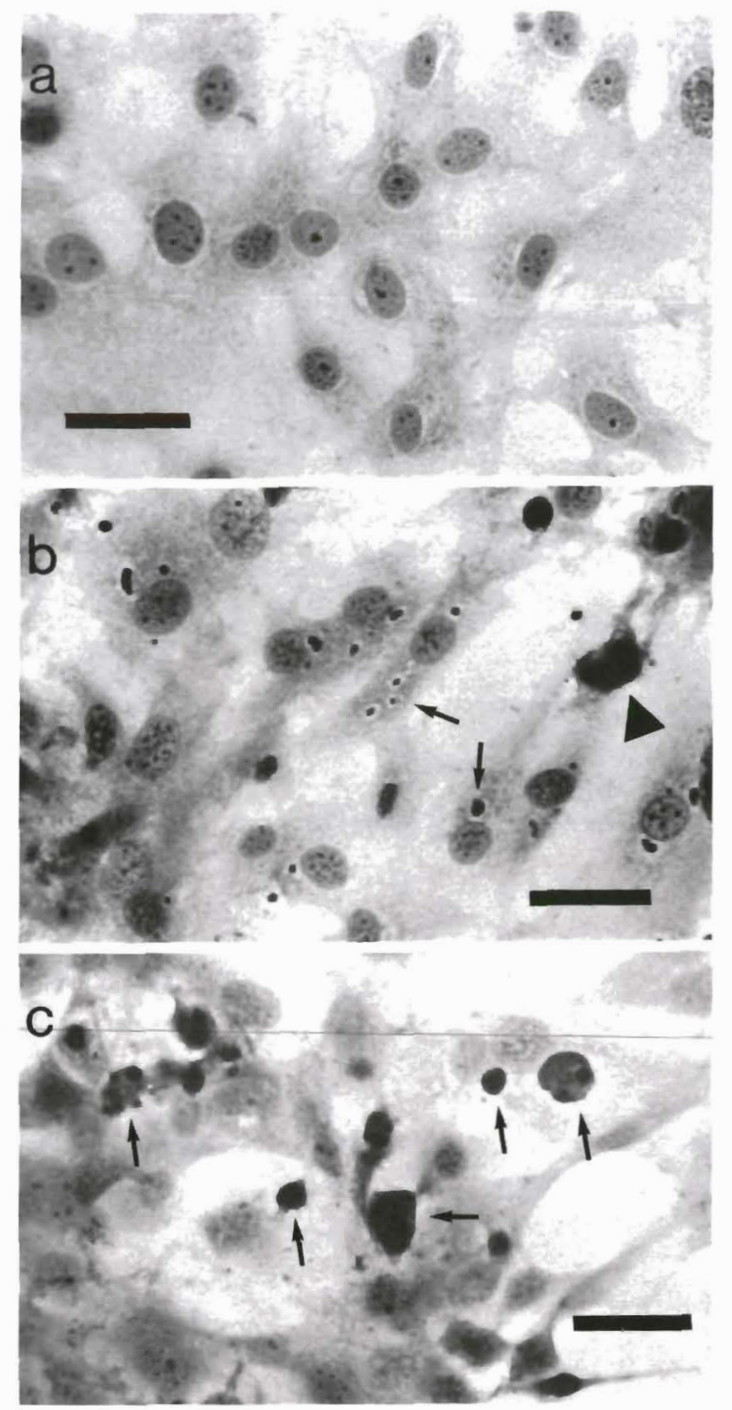

Fig. 1. Monolayers of BF-2 cells. (a) Normal monolayer. (b) Basophilic inclusion bodies in cytoplasm of BF-2 monolayer $4 \mathrm{~h}$ after infection with the virus. Many cells contain multiple inclusions (arrows). The arrowhead marks a contracted artifactual cell common in BF-2 monolayers. (c) Advanced cytopathic effect $6 \mathrm{~h}$ after infection with the virus. Cytoplasmic inclusions are aggregated (arrows) and some nuclei are pyknotic. Cell boundaries are less distinct $(\mathrm{H} \& \mathrm{E})_{i} .600 \times$, scale bar $=20 \mu \mathrm{m}$

nucleocapsid was $128 \pm 8 \mathrm{~nm}$ (range: 117 to $146 \mathrm{~nm}$, $\mathrm{n}=14$ ) and of the envelope $147 \pm 8 \mathrm{~nm}$ (range: 137 to 156, $\mathrm{n}=11$ ).

In thin sections viral particles in cells had cubic symmetry with hexagonal and pentagonal cross sections (Fig. 3). Average diameter from vertex to vertex of the top $25 \%$ of 40 measured particles was $172 \pm 5 \mathrm{~nm}$ (max: $176 \mathrm{~nm}$ ). Viruses had a central, spherical, densely staining core surrounded by a capsid and were not enveloped in cells. In the sections examined no

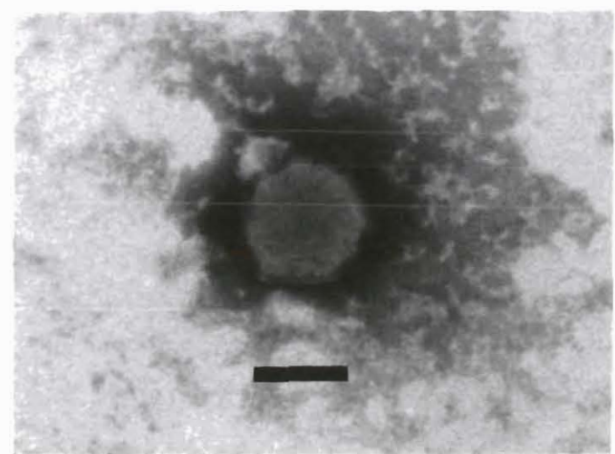

Fig 2. Negative contrast stain of virus isolated from Limnodynastes ornatus. Note the envelope closely adjacent to the nucleocapsid. TEM; phosphotungstic acid; $90000 \times$, scale bar $=100 \mathrm{~nm}$

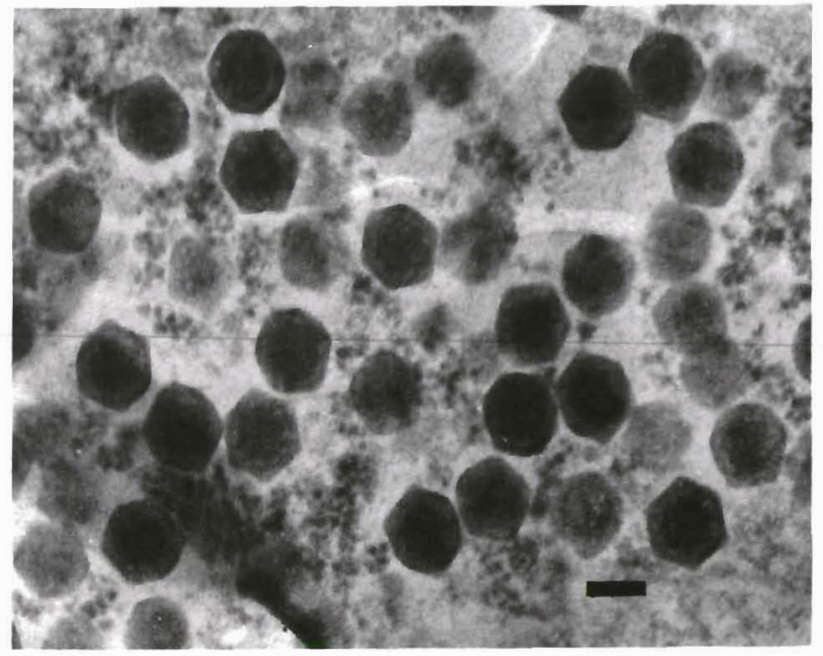

Fig 3. Unenveloped virus particles in cytoplasm of BF-2 cell. TEM; $60000 \times$, scale bar $=100 \mathrm{~nm}$

viral particles were found in the process of escaping from cells.

\section{Biological characteristics of the virus}

After treatment with diethyl ether for $18 \mathrm{~h}$, titres were reduced from $10^{7.8} \mathrm{ml}^{-1}$ to $10^{4.3} \mathrm{ml}^{-1}$, a reduction of about $99 \%$. Ether sensitivity confirmed the presence of a lipid-soluble envelope essential for infectivity. Viral titres were markedly reduced after $1 \mathrm{~h}$ at $\mathrm{pHs}$ of 2 , 3,10 and 11 (Table 2). Titre was unchanged after $6 \mathrm{~h}$ at 25 and $37^{\circ} \mathrm{C}$ (Table 3). Titre was reduced by $99.9 \%$ and $99.999 \%$ after $0.5 \mathrm{~h}$ and $1 \mathrm{~h}$ at $56{ }^{\circ} \mathrm{C}$ respectively and no viability was detected at 2 and $6 \mathrm{~h}$.

Culture temperature affected replication in all cell lines (Table 4). Growth of virus occurred in Atlantic 
Table 2. Infectivity of the virus isolated from Limnodynastes ornatus after $1 \mathrm{~h}$ in DMEM at different $\mathrm{pH}$

\begin{tabular}{|cc|}
\hline $\mathrm{pH}$ & $\begin{array}{c}\text { Titre } \\
\left(\text { TCID }_{50} \mathrm{ml}^{-1}\right)\end{array}$ \\
\hline Initial & $10^{5.68}$ \\
2 & 0 \\
3 & $10^{1.09}$ \\
4 & $10^{5.11}$ \\
5 & $10^{4.11}$ \\
6 & $10^{4.18}$ \\
7 & $10^{4.85}$ \\
8 & $10^{5.11}$ \\
9 & $10^{4.68}$ \\
10 & $10^{1.85}$ \\
11 & $10^{2.35}$ \\
\hline
\end{tabular}

Table 3. Stability of the virus isolated from Limnodynastes ornatus at different temperatures. Titres are given as $\mathrm{TCID}_{50}$ $\mathrm{ml}^{-1}$. nd: not done

\begin{tabular}{|cccccc|}
\hline Temp. $\left({ }^{\circ} \mathrm{C}\right)$ & Initial & $0.5 \mathrm{~h}$ & $1 \mathrm{~h}$ & $2 \mathrm{~h}$ & $6 \mathrm{~h}$ \\
\hline 25 & $10^{7.85}$ & nd & nd & nd & $10^{7.52}$ \\
37 & $10^{7.85}$ & nd & nd & nd & $10^{7.98}$ \\
56 & $10^{7.85}$ & $10^{3.27}$ & $10^{2.23}$ & 0 & 0 \\
\hline
\end{tabular}

Table 4. Replication of the virus isolated from Limnodynastes ornatus 1 wk post-inoculation in different cell cultures at different temperatures. Titres are given as $\mathrm{TCID}_{50} \mathrm{ml}^{-1}$. nd: not done; $(-)$ : contaminated

\begin{tabular}{|c|c|c|c|c|c|c|}
\hline \multirow[t]{2}{*}{ Cell line } & \multirow{2}{*}{$\begin{array}{l}\text { Initial } \\
\text { titre }\end{array}$} & \multicolumn{5}{|c|}{ Final titre after $7 \mathrm{~d}$} \\
\hline & & $20^{\circ} \mathrm{C}$ & $25^{\circ} \mathrm{C}$ & $30^{\circ} \mathrm{C}$ & $34^{\circ} \mathrm{C}$ & $37^{\circ} \mathrm{C}$ \\
\hline \multicolumn{7}{|l|}{ Insect } \\
\hline AA.A20 & $10^{2}$ & nd & $10^{2}$ & nd & nd & nd \\
\hline AG. 55 & $10^{2}$ & nd & $10^{2}$ & nd & nd & nd \\
\hline C636 & $10^{2}$ & nd & $10^{2}$ & nd & nd & nd \\
\hline \multicolumn{7}{|l|}{ Fish } \\
\hline AS & $10^{2.11}$ & $10^{1.85}$ & $10^{3.85}$ & $10^{2.85}$ & $10^{2.11}$ & 0 \\
\hline $\mathrm{BB}$ & $10^{2.5}$ & $10^{7.35}$ & $10^{7.68}$ & $10^{7.35}$ & $10^{2.85}$ & $10^{2.85}$ \\
\hline BF-2 expt 1 & $10^{3.4}$ & $10^{8.33}$ & $10^{6.5}$ & $10^{6.76}$ & $10^{1.76}$ & $10^{1.5}$ \\
\hline BF-2 expt 2 & $10^{3.2}$ & $10^{8.67}$ & $10^{8.67}$ & $10^{8.17}$ & $10^{2.67}$ & $10^{3.0}$ \\
\hline FHM & $10^{2.35}$ & $10^{7.68}$ & $10^{8.68}$ & $10^{6.85}$ & $10^{2.11}$ & $10^{2.35}$ \\
\hline RTG & $10^{2.35}$ & $10^{6.85}$ & $10^{8.85}$ & $10^{8.11}$ & $10^{2.85}$ & 0 \\
\hline \multicolumn{7}{|l|}{ Mammal } \\
\hline BT & $10^{2.85}$ & $10^{4.65}$ & $10^{7.35}$ & $10^{6.85}$ & $10^{1.11}$ & $10^{1.11}$ \\
\hline CSL235 expt 1 & $10^{2.5}$ & $10^{5.85}$ & $10^{7.85}$ & $10^{7.85}$ & $10^{4.11}$ & $10^{3.68}$ \\
\hline CSL235 expt 2 & $10^{2.11}$ & $10^{4.11}$ & $10^{8.85}$ & $10^{7.11}$ & $10^{2.65}$ & $10^{1.85}$ \\
\hline FK & $10^{2.35}$ & $10^{4.85}$ & $10^{8.35}$ & - & $10^{1.11}$ & $10^{1.85}$ \\
\hline MDBK & $10^{2.8}$ & $10^{4.67}$ & $10^{5.43}$ & $10^{5.17}$ & $10^{4.17}$ & $10^{3.0}$ \\
\hline PS/EK & $10^{2.35}$ & $10^{5.35}$ & $10^{7.85}$ & $10^{6.65}$ & $10^{4.11}$ & $10^{1.85}$ \\
\hline Vero & $10^{2.9}$ & $10^{6.11}$ & $10^{8.11}$ & $10^{5.85}$ & $10^{1.85}$ & $10^{1.58}$ \\
\hline
\end{tabular}

salmon, but only at $25^{\circ} \mathrm{C}$ and titre was low compared to other cell lines. Replication did not occur at $37^{\circ} \mathrm{C}$ in any cell line or at $34^{\circ} \mathrm{C}$ in any fish cell line. Replication did occur at $34{ }^{\circ} \mathrm{C}$ in some mammalian cell lines, but titres were reduced. Maximum titres for all cell lines were attained at 20 or $25^{\circ} \mathrm{C}$. Analysis of titres after omission of AS showed 2 groups, with 20,25 and $30^{\circ} \mathrm{C}$ having titres higher than post-absorption, $34^{\circ} \mathrm{C}$ and $37^{\circ} \mathrm{C}$ (GANOVA). The vertebrate class of origin of cells was only significant at $20^{\circ} \mathrm{C}$ with fish cell lines having higher titres than mammalian cell lines (1-way ANOVA, p $<0.001$ ).

\section{Nucleic acid of virus}

Inclusion bodies had an apple-green fluorescence when stained with acridine orange and examined with ultraviolet light, indicating that double-stranded DNA was present. BUdR and IUdR in the media prevented CPE development and virus multiplication (Table 5). This inhibition was prevented by the higher concentration $\left(500 \mu \mathrm{g} \mathrm{ml}^{-1}\right)$ of thymidine while the lower concentration $\left(100 \mu \mathrm{g} \mathrm{ml}^{-1}\right)$ increased the titre, but not to control levels (Table 5). Inclusion of AZC in the media inhibited growth (Table 5).

Table 5. Effect of inhibitors of DNA synthesis with and without thymidine and the effect of an inhibitor of DNA methylation on infection of BF-2 cell cultures with the virus isolated from Limnodynastes ornatus. Titres were measured at $7 \mathrm{~d}$ postinoculation and are given as $\mathrm{TCID}_{50} \mathrm{ml}^{-1}$. AZC: azocytosine; BUdR: 5-bromo-2'-deoxyuridine; IUdR: 5-iodo-2'-deoxyuridine; thym: thymidine

\begin{tabular}{|c|c|c|c|c|}
\hline Inhibitor & $\begin{array}{l}\text { Conc } \\
\left(\mu \mathrm{g} \mathrm{ml}^{-1}\right)\end{array}$ & CPE & $\begin{array}{l}\text { Titre } \\
\text { Initial }\end{array}$ & Final \\
\hline \multicolumn{5}{|c|}{ Inhibitors of DNA synthesis } \\
\hline BUdR & 200 & neg & $10^{2.11}$ & $10^{1.85}$ \\
\hline BUdR & 100 & neg & $10^{2.11}$ & $10^{2.11}$ \\
\hline IUdR & 200 & neg & $10^{2.11}$ & $10^{2.11}$ \\
\hline IUdR & 100 & neg & $10^{2.11}$ & $10^{2.35}$ \\
\hline Thymidine & 500 & $4+$ & $10^{2.11}$ & $10^{6.35}$ \\
\hline Thymidine & 100 & $4+$ & $10^{2.11}$ & $10^{6.58}$ \\
\hline BUdR + thym & $100+500$ & $4+$ & $10^{2.11}$ & $10^{6.11}$ \\
\hline BUdR + thym & $100+100$ & $2+$ & $10^{2.11}$ & $10^{3.85}$ \\
\hline IUdR + thym & $100+500$ & $4+$ & $10^{2.11}$ & $10^{6.35}$ \\
\hline IUdR + thym & $100+100$ & $2+$ & $10^{2.11}$ & $10^{4.85}$ \\
\hline Virus alone & 0 & $4+$ & $10^{2.11}$ & $10^{7.11}$ \\
\hline \multicolumn{5}{|c|}{ Inhibitor of DNA methylation } \\
\hline $\mathrm{AZC}$ & 2.5 & neg & $10^{1.68}$ & $10^{2.85}$ \\
\hline Virus alone & 0 & $4+$ & $10^{1.85}$ & $10^{7.85}$ \\
\hline
\end{tabular}

\section{DISCUSSION}

This is the first description of a virus isolated from amphibians in Australia. The size and morphology of this virus, the presence of a lipid envelope, its CPE and the presence of DNA, are consistent with an iridovirus (Francki et al. 1991). The genus Ranavirus of the 
Iridoviridae have methylated cytosine residues and AZC inhibits methylation (Essani \& Granoff 1989). AZC inhibition of replication of the isolate indicates that DNA methylation is an essential process (Goorha et al. 1984). The isolate is similar in size, biological characteristics and CPE to ranaviruses isolated in North America (Essani \& Granoff 1989). The North American ranaviruses 1, 2 and 3 will not replicate above $33^{\circ} \mathrm{C}$ (Granoff et al. 1965, Clark et al. 1969, Gravell \& Granoff 1970, Essani \& Granoff 1989). The replication of the isolate from Limnodynastes ornatus showed a similar temperature sensitivity. The virus did not grow at $37^{\circ} \mathrm{C}$ in all cell lines tested and at $34^{\circ} \mathrm{C}$ in fish cell lines used. However, although titres of this isolate were reduced at $34{ }^{\circ} \mathrm{C}$ in mammalian cells, replication occurred in 3 of the 7 mammalian cell lines tested.

The Ranaviruses replicated in 9 mammalian cell lines, 21 reptile cell lines, primary chick embryo cell lines, 4 fish cell lines, but did not grow in the piscine cell lines BB and CAR (Darlington et al. 1966, Clark et al. 1968, Essani \& Granoff 1989). Frog Virus 3 did not multiply in the mealworm Tenebrio molitor (Lunger \& Came 1966). Our isolate grew to high titre in 4 fish cell lines and 6 mammalian cell lines. It grew to low titre in the fish cell line AS, and failed to replicate in 4 insect cell lines. Replication of our isolate in BB cells is a biological difference from the ranaviruses. We did not test growth in CAR, another cell line in which ranaviruses 1, 2, and 3 failed to grow (Essani \& Granoff 1989).

This virus is the third iridovirus-like agent isolated from poikilothermic vertebrates in Australia. Epizootic haematopoietic necrosis virus (EHNV) was isolated from redfin perch Perca fluviatilis (Langdon et al. 1986, Langdon \& Humphrey 1987) and an EHNV-like agent was isolated from rainbow trout Salmo gairdneri (Langdon et al. 1988), but further study is required to determine the degree of similarity between the 2 isolates (Eaton et al. 1991). The morphologies of EHNV and our isolate are similar and they cause a similar CPE. Like our isolate and the ranaviruses, EHNV also has methylated DNA (Eaton et al. 1991). The only biological difference noted is higher titres at lower temperatures with EHNV, while our isolate replicates equally well at 20 to $30^{\circ} \mathrm{C}$. Although our isolate and EHNV can not be distinguished on published data, there are no reports of attempted infections of mammalian or insect cells with EHNV.

A number of iridoviruses have been found in fish, but only 4, fish lymphocystis disease virus (FLDV), EHNV, goldfish virus (GFV) and sheatfish virus, appear to have been isolated and characterised (Berry et al. 1983, Langdon \& Humphrey 1987, Ahne et al. 1989). FLDV is distinct from the ranaviruses, GFV and EHNV (Essani \& Granoff 1989, Eaton et al. 1991). EHNV differs in protein profiles and DNA restriction pattern from GFV and is similar to, but appears to have some differences from, the North American ranaviruses (Eaton et al. 1991). Since GFV is unable to infect mammalian cells, our isolate is different in this respect.

Our isolate is possibly a new strain of iridovirus. A comparative study with the ranaviruses and the iridoviruses of fish, particularly EHNV and sheatfish virus, using monoclonal antibodies and characterisation of DNA and proteins is required for clarification of its status.

Acknowledgements. We thank Tricia O'Shea, Marion Hulme, Sally Bolton and Dick Jones for expert technical assistance, John Humphries of the Australian Fish Health Reference Laboratory for the original provision of BF-2 and Dr Alex Hyatt for advice and review of the manuscript. This study was supported by a James Cook University Prestige Research Grant to R.S. and by funds provided by the Council of Nature Conservation Ministers (CONCOM).

\section{LITERATURE CITED}

Ahne, W., Schlotfeld, H. J., Thomsen, I. (1989). Fish viruses: isolation of an icosahedral cytoplasmic deoxyribovirus from sheatfish (Silurus glanis). J. Vet. Med. B36: 333-336

American Type Culture Collection (1988). American type culture catalogue of cell lines and hybridomas, 6th edn. American Type Culture Collection, Rockville, MD

Andrewes, C. H., Horstmann, D. M. (1949). The susceptibility of viruses to ethyl ether. J. gen. Microbiol. 3: 290-297

Berry, E. S., Shea, T. B., Gabliks, J. (1983). Two iridovirus isolates from Carassius auratus (L.). J. Fish Dis. 6: 501-510

Clark, H. F., Brennan, J. C., Zeigel, R. F., Karzon, D. T. (1968). Isolation and characterization of viruses from the kidneys of Rana pipiens with renal adenocarcinoma before and after passage in the red eft (Triturus viridescens). J. Virol. 2: $629-640$

Clark, H. F., Gray, C., Fabian, F., Zeigel, R., Karzon, D. T. (1969). Comparative studies of amphibian cytoplasmic virus strains isolated from the leopard frog, bullfrog, and newt. In: Mizell, M. (ed.) Biology of amphibian tumours. Springer-Verlag, Berlin, p. 310-326

Commonwealth Serum Laboratories Cell Culture Handbook (1976). Commonwealth Serum Laboratories, Parkville

Darlington, R. W., Granoff, A., Breeze, D. C. (1966). Viruses and renal carcinoma of Rana pipiens. II. Ultrastructural studies and sequential development of virus isolated from normal and tumor tissue. Virol. 29: 149-156

Eaton, B. T., Hyatt, A. D., Hengstberger, S. (1991). Epizootic haematopoietic necrosis virus: purification and classification. J. Fish Dis. 14: 157-169

Essani, K., Granoff, A. (1989). Amphibian and piscine iridoviruses proposal for nomenclature and taxonomy based on molecular and biological properties. Intervirol. 30: $187-193$

Francki, R. I. B., Fauquet, C. M., Knudson, D. L., Brown, F. (1991). Classification and nomenclature of viruses. Springer-Verlag, Vienna

Freeland, W. J. (1985). The need to control cane toads. Search 16: $211-215$ 
Goorha, R., Granoff, A., Willis, D. B., Murti, K. G. (1984). The role of DNA methylation in virus replication: inhibition of frog virus 3 replication by 5 -azacytidine. Virol. 138: 94-102

Gorman, B. M., Leer, J. R., Filippich, C., Goss, P. D., Doherty, R. L. (1975). Plaquing and neutralization of arboviruses in the PS-EK line of cells. Aust. J. med. Technol. 6: 65-70

Granoff, A. (1983). Amphibian herpesvirus. In: Roizmann, B. (ed.) The herpesviruses. Plenum Publ. Corp., p. $367-384$

Granoff, A. (1989). Viruses of Amphibia: an historical perspective. In: Ahne, W., Kurstak, E. (eds.) Viruses of lower vertebrates. Springer-Verlag, Berlin, p. 3-12

Granoff, A., Came, P. E., Rafferty, K. A. (1965). The isolation and properties of viruses from Rana pipiens: their possible relationship to the renal adenocarcinoma of the leopard frog. Ann. N.Y. Acad. Sci. 126: 237-255

Gravell, M., Granoff, A. (1970). Viruses and renal carcinoma of Rana pipiens. IX. The influence of temperature and host cell on replication of frog polyhedral cytoplasmic deoxyriboviruses (PCDV). Virol. 41: 596-602

Hamparian, V. V., Ketler, A., Hilleman, M. R. (1961). Recovery of cold viruses (Coryzavirus) from cases of common cold in human adults. Proc. Soc. exp. Biol. Med. 108: 444-453

Ketler, A., Hamparian, V. V., Hilleman, M. R. (1962). Characterization and classification of ECHO 28-Rhinovirus Coryzavirus agents. Proc. Soc. exp. Biol. Med. 110: 821-831

Langdon, J. S., Humphrey, J. D. (1987). Epizootic haematopoietic necrosis, a new viral disease in redfin

Responsible Subject Editor: P. Zwart, Utrecht, The Netherlands perch, Perca fluviatilis L., in Australia. J. Fish Dis. 10: 289-297

Langdon, J. S., Humphrey, J. D., Williams, L. M. (1988). Outbreaks of an EHNV-like iridovirus in cultured rainbow trout, Salmo gairdneri Richardson, in Australia. J. Fish Dis. 11: 93-96

Langdon, J. S., Humphrey, J. D., Williams, L. M., Hyatt, A. D., Westbury, H. A. (1986). First virus isolation from Australian fish: an iridovirus-like pathogen from redfin perch, Perca fluviatilis L. J. Fish Dis. 9: 263-268

Lunger, P. D., Came, P. E. (1966). Cytoplasmic viruses associated with Lucké tumor cells. Virol. 30: 116-126

Reed, L. J., Muench, H. (1938). A simple method of estimating fifty percent endpoints. Am. J. Hyg. 27: 493-542

Smith, J. R. (1986). Studies on canine parvovirus associated disease and control. Ph.D. thesis, James Cook Univ., Townsville

Speare, R. (1990). A review of the diseases of the cane toad, Bufo marinus, with comments on biological control. Aust. Wildl. Res. 17: 387-410

Speare, R., Freeland, W. J., Bolton, S. J. (1991). A possible iridovirus in erythrocytes of Bufo marinus in Costa Rica. J. Wildl. Dis. 27: 457-462

Spratt, D. M. (1990). The role of helminths in the biological control of mammals. Inter. J. Parasitol. 20: 543-550

Thompson, S. W. (1966). Selected histochemical and histopathological methods. Charles C. Thomas Publisher, Springfield

Wolf, K., Gravell, M., Malsberger, R. G. (1966). Lymphocystis virus: isolation and propagation in centrachid fish cell lines. Science 151: 1004-1005

Manuscript first received: February 16, 1992

Revised version accepted: June 12, 1992 